\title{
Antibacterial Activity of Sugarcane Bagasse Nanocellulose Biocomposite with Chitosan Against Escherichia coli
}

\author{
A'yunil Hisbiyah", Lilik Nur Fadhilah, Rohmawati Hidayah ${ }^{3}$ \\ Organic Chemistry Laboratory, STIKES RS Anwar Medika, \\ J1. Raya By Pass Krian KM 33 Balongbendo, Sidoarjo, 61263, Indonesia \\ *Corresponding author: yuihisbi@gmail.com
}

Received: December 2020; Revision: April 2021; Accepted: May 2021; Available online: June 2021

\begin{abstract}
Antibacterials have been used to treat infectious diseases in both humans and animals since 1929. Along with their use, there is resistance to some antibacterials. $43 \%$ of Escherichia coli is resistant to various types of antibiotics. Therefore, research on the development of antibacterial ingredients is always being developed. Nanocellulose has received a lot of attention on its application of antibacterial material support. Meanwhile, chitosan is an antibacterial biopolymer with a brittle structure, hence nanocellulose is added to chitosan film to increase its structural stability. In this study, nanocellulose was extracted from sugarcane bagasse through a combination method of sulfuric acid hydrolysis with ultrasonic waves. The effect of addition of nanocellulose to chitosan mechanical properties was investigated. Scanning Electron Microscopy (SEM) characterization showed that there were differences in morphology between nanocellulose, chitosan, and nanocellulose-chitosan biocomposites. The result of X-Ray Diffraction and Fourier-transformed infrared spectroscopy analysis showed that biocomposites was successfully formed. The average size of nanocellulose particle was $132.67 \mathrm{~nm}$. Nanocellulose-chitosan biocomposites with a ratio of 10:2 have the best antibacterial activity against Escherichia coli than other biocomposite ratios.
\end{abstract}

Keywords: Antibacterial activity, nanocellulose-chitosan, Escherichia coli, sugarcane bagasse, ultrasonication.

DOI: $10.15408 / j k v . v 7 i 1.18718$

\section{INTRODUCTION}

Antibacterials have been used to treat infectious diseases in humans and animals since 1929. Along with their use, there is resistance to several antibacterials that can threaten the health of millions of lives. The rate of bacterial resistance to drugs is increasing rapidly. The Antimicrobial Resistance In Indonesia (AMRIN-Study) in 2011 proved that of 2,494 individuals spread throughout Indonesia, $43 \%$ of Escherichia coli were resistant to various types of antibiotics, including ampicillin, cotrimoxazole, and chloramphenicol (Hadi et al., 2013). Therefore, research related to the development of antibacterial ingredients is needed. Nanocellulose has received a lot of attention in its application as antibacterial material support (Juanjuan Li et al., 2018). The antibacterial properties of nanocellulose are due to their physical properties, excellent biological properties, and special surface chemical properties. Nanocellulose has a large number of hydroxyl groups hence it has a stable structure in water (Phanthong et al., 2018).

Several studies have proven the ability of nanocellulose as an antibacterial support material (George \& Sabapathi, 2015; Xu et al., 2019). Nanocellulose can be formed biocomposite with natural materials to increase its utility (Gunathilake et al., 2017; Hänninen et al., 2018; Oksman et al., 2016; Szymańska-Chargot et al., 2019). Nanocellulose can increase the antibacterial activity of chitosan against $B$. cereus, Salmonella typhimurium, $S$. aureus, Escherichia coli (Abdul Khalil et al., 2016). Chitosan is a biopolymer compound produced from the chitin of crustacean class, such as shrimp and crab, wich can be used as food packaging material because it is easily degraded, edible film, antioxidant, and 
antibacterial (Cheung et al., 2015). Chitosan polymers are easily brittle so that nanocellulose is combined to increase the stability of its structure (Szymańska-Chargot et al., 2019).

Nanocellulose can be extracted from agricultural waste, one of which is sugarcane bagasse (Rahmi et al., 2017; Saputri et al., 2018). Nanocellulose extraction methods from bagasse that have been successfully carried out including the high pressure mechanical method (Jihua et al., 2012), the enzymatic hydrolysis method (Ribeiro et al., 2019), the acid hydrolysis method (Wulandari et al., 2016), and the ultrasonication method (Shahi et al., 2020). The nanocellulose extraction method used in this study is a combination of the acid hydrolysis method with ultrasonic waves. Optimizations of nanocellulosechitosan ratio in biocomposite were carried out in this study to obtain the correct material parameters with high antibacterial activity against Escherichia coli.

The resulting biocomposite then characterized by using several instruments. Xray diffraction (XRD) analysis was used to characterize the crystalline structure of nanocellulose and biocomposite. Fouriertransformed infrared spectroscopy (FT-IR) analysis was used to characterize the chemical composition of extracted cellulose and nanocellulose that verifying the removal of lignin and hemicellulose during the cellulose extraction process from sugarcane bagasse. Scanning Electron Microscope (SEM) was used to characterize the morphology of sugarcane bagasse, nanocellulose, and biocomposite. Particle size analyzer (PSA) was used to determine the particle size of nanocellulose.

\section{MATERIALS AND METHOD Instrumentation and Materials}

The material used in this research are Sugarcane bagasse gathered in Sidoarjo (East Java, Indonesia) were used in this study. The chemical reagent use were $\mathrm{NaOH}$ (p.a Merck), $\mathrm{NaClO}$ (p.a Merck), $\mathrm{H}_{2} \mathrm{SO}_{4}$ (Merck), Filter paper (Whatmann No.44), demineralized water (Bratachem), Escherichia coli isolate from Institue of Tropical Disease-Universitas Airlangga (ATCC 25922), Natrium Agar Media (Merck), Dimethyl sulfoxide (DMSO Merck). The instruments used in this research are glasses equipment, ultrasonicator, Oven
(DGG 9053A), analytical balance (Ohaus px224/E), sentrifuge, microplate reader, Laminar Air flow, Autoclave. The morphology of the biocomposite was analyzed byScanning Electron Microscope (SEM HITACHI FLEXSEM 1000). Functional groups of biocomposite were analyzed by flexible benchtop FTIR spectrometer Cary 360. The biocomposite crystalline phase was analyzed by X-ray diffractometer (XRD Philip analytical). Nanocelullose particle size was analyzed using particle size analyzer (PSA Horiba Scientific SZ-100).

\section{Isolation nanocellulose form Sugarcane Bagasse}

The nanocellulose isolation method used was (Mandal \& Chakrabarty, 2011) a modified method by using an ultrasonicator. Clean and dry sugarcane bagasse (SB) was cut into small pieces and chorused into finer powder, then was placed in the oven at $60^{\circ} \mathrm{C}$ for 16 hours. The dry bagasse was put into the Erlenmeyer flask, then $250 \mathrm{~mL}$ of $17.5 \% \mathrm{w} / \mathrm{v}$ $\mathrm{NaOH}$ was added. The mixture was ultrasonicated for 2 hours at $70{ }^{\circ} \mathrm{C}$. Furthermore, the mixture was then filtered. The residue that has been produced was then bleached with a $0.7 \% \mathrm{v} / \mathrm{v} \mathrm{NaClO}$ solution, then the mixture was sonicated for $2 \times 1$ hours. The residue produced during the bleaching process was washed with distilled water. The residue obtained was then dried in an oven at $60{ }^{\circ} \mathrm{C}$ to obtain cellulose (C-SB). A total of 5 grams of $\mathrm{C}-\mathrm{SB}$ was reacted with $25 \mathrm{~mL}$ of $45 \% \mathrm{H}_{2} \mathrm{SO}_{4}$. Hydrolysis was carried out with the aid of an ultrasonicator at a temperature of $70^{\circ} \mathrm{C}$ for 90 minutes. After that the mixture was neutralized with $28 \mathrm{~mL}$ of $0.5 \mathrm{M} \mathrm{NaOH}$ and washed with distilled water until the $\mathrm{pH}$ was neutral. Then the mixture is was centrifuged to obtain nanocellulose (NC-SB). The NC-SB was then dried at $60{ }^{\circ} \mathrm{C}$ until the constant weight was obtained ( $\mathrm{Xu}$ et al., 2019).

\section{Biocomposite preparation}

Preparation of chitosan-nanocellulose (CHIT/NC-SB) biocomposites using the method belongs to Szymańska-Chargot et al. (2019) with modifications on the membrane formation process. Chitosan was dissolved in $2 \%$ acetic acid to obtain 3\% w/v chitosan solution. Furthermore, the nanocellulose was 
cultured in 3\% chitosan solution with various mass ratios of CHIT:NC-SB for 8 hours at 45 ${ }^{\circ} \mathrm{C}$ (Table 1).

Table 1. Mass ratio of Nanocellulose-Sugarcane Bagasse and Chitosan in biocomposite

\begin{tabular}{cc}
\hline Biocomposite & $\begin{array}{c}\text { Mass ratio } \\
\text { CHIT:NC-SB }\end{array}$ \\
\hline $\mathbf{0}$ & $10: 0$ \\
$\mathbf{1}$ & $10: 1$ \\
$\mathbf{2}$ & $10: 2$ \\
$\mathbf{3}$ & $10: 3$ \\
$\mathbf{4}$ & $10: 4$ \\
$\mathbf{5}$ & $10: 5$ \\
\hline
\end{tabular}

Then the mixture was poured into 7,5 $\mathrm{cm} \times 10 \mathrm{~cm}$ acrylic molds to form a membrane. Furthermore, the biocomposite membrane was dried for 72 hours. The biocomposite obtained was then characterized. The characterizations were carried out by SEM, FT-IR, XRD.

\section{Antibacterial activity test against Escherichia coli}

Antibacterial activity test of nanocellulose-chitosan biocomposites was carried out on Escherichia coli as gramnegative bacteria. Antibacterial activity test was carried out thrice, where Chloramphenicol was used as a positive control and $10 \%$ DMSO was used as a negative control. Antibacterial activity test was carried out using the well diffusion method. After the Natrium Agar media in the petri dish solidified, 50 bacterial suspension was inoculated and evenly spread on the surface of the media using cotton buds. Next , a well was made in a petri dish with a diameter of $7 \mathrm{~mm}$ for each well. The biocomposite with various ratio of concentration was cut to a size of $7 \times 7 \mathrm{~mm}$. Futhermore, each of the biocomposites were placed into the well, then incubated for 24 hours at $37{ }^{\circ} \mathrm{C}$ and observed the formed clear zone. The diameter of the zone of inhibition was measured using a caliper (Amanda et al., 2020).

\section{RESULT AND DISCUSSION Ectraction of Nanocellulose from Sugarcane Bagasse}

Extraction of nanocellulose from bagasse consisted of three stages, which are alkali treatment, bleaching, and acid hydrolysis. All these steps took place with the help of an ultrasonicator. Starting from raw material (SB), the first stage of the extraction was alkali treatment or delignification using $\mathrm{NaOH}$ to remove lignin from bagasse. In this process, fiber development occured hence the hemicellulose, mineral salts, and ash are lost, and produce brownish yellow pulp (Sheltami et al., 2012). The second stage of theextraction was a bleaching treatment using $0.7 \% \mathrm{NaOCl}$ to obtain white cellulose. The third stage of the extraction was acid hydrolysis using $45 \%$ $\mathrm{H}_{2} \mathrm{SO}_{4}$. Strong acids can remove the amorphous part of cellulose chain (Effendi $e t$ al., 2015). The colour of the powder changed from brownish yellow (Figure 1.a) to light brown (Figure 1.b) after alkali treatment and became white after bleaching treatment (Figure 1.c). After the hydrolysis stage, the colour of material changed from white into brown (Figure 1.d). NC-SB produced from 60 grams of bagasse is 6.890 grams, therefore the yield of nanocellulose isolation from bagasse is $11.483 \%$. The average size of nanocellulose particle was $132.67 \mathrm{~nm}$.

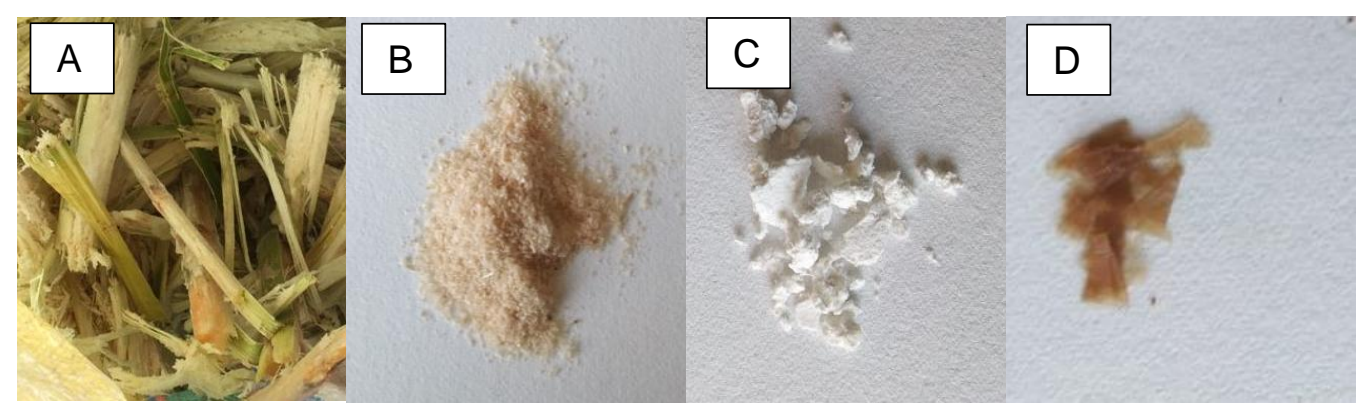

Figure 1. a)Sugarcane bagasse (SB); b) SB After alkali treatment; c) Cellulose; d) Nanocellulose. 


\section{Preparation of Nanocellulose-Chitosan Biocomposite}

The results of NC-SB/CHIT biocomposite production at various concentration ratios indicated that the more chitosan ratio in biocomposite, the higher the viscosity of the biocomposite mixture. This causes biocomposite mixture to rapidly aggregate during the membrane imposing process so that the surface of the biocomposite membrane is not homogeneous. The temperature during the stirring of mixture and drying of the membrane plays an important role because it can cause sublimation and phase separation hence the membrane formed will agglomerate and create the porous membrane (Hu et al., 2016).

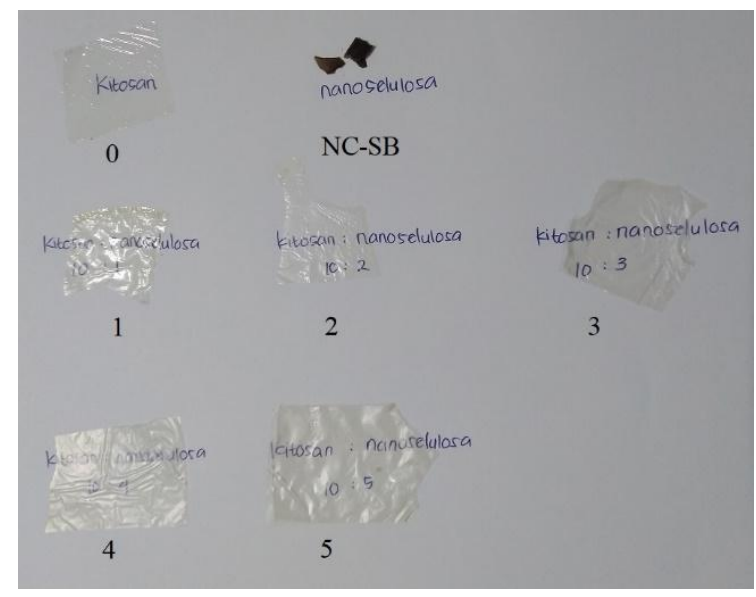

Figure 2. The membrane biocomposite of CHIT/NC-SB

After the biocomposite mixture was homogenous, then the mixture was printed on acrylic $7.5 \mathrm{~cm} \times 10 \mathrm{~cm}$ using the casting method. The membrane will form after being heated at $60{ }^{\circ} \mathrm{C}$ for 72 hours. It can be seen that the higher the chitosan concentration ratio, the lower the transparency of the biocomposite membrane and the color of the bicomposite membrane will become increasingly yellow (Figure 2).

\section{Antibacterial Activity of Nanocellulose- Chitosan against Escherichia coli}

Inhibition test of Escherichia coli bacteria by nanocellulose-chitosan biocomposite can be observed from the formation of clear zones (Figure 2). The clear zone is an area where Escherichia coli is not covered, so this area is expressed as the area of bacterial inhibition. The area of inhibition indicated the effectiveness of biocomposites in inhibiting bacteria. The wider the clear zone, the better the ability of biocomposite to inhibit bacteria (Szymańska-Chargot et al., 2019).

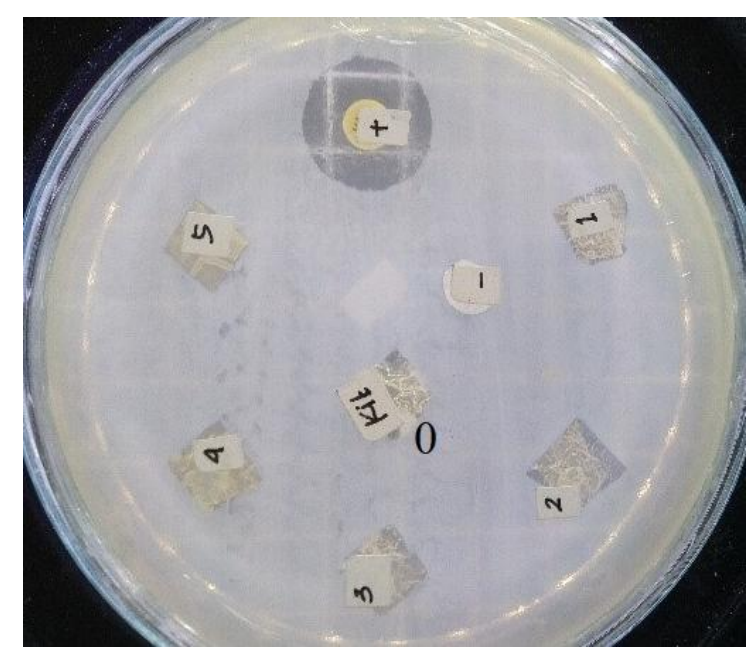

Figure 2. Nanocellulose-Chitosan Biocomposite Inhibition Test Against Escherichia coli.

The results showed the most optimum area of inhibition was on the biocomposite membrane with a ratio of $10: 2$, namely the area of inhibition of $8.5 \mathrm{~mm}^{2}$ (Table 2), while the area of chitosan inhibition was $7 \mathrm{~mm}^{2}$. From these results, the addition of nanocellulose was proven to be able to increase the ability of chitosan to inhibit Escherichia coli by $21.43 \%$. The biocomposite mixture is thought to be able to inhibit microbes by destroying the peptidoglycan structure in the cell wall and denaturing proteins, resulting in enzyme deactivation. The deactivated enzyme include phosphodiesterase, isocitrate dehydrogenase, Glucose-5-phospate Dehydrogenase, NADH oxidase, glutamate-pyruvate aminotransferase AlaB, alanin transaminase (Calcott, 1982; Kim et al., 2010; Nieß et al., 2019). This is because the process of inhibiting the growth of microorganisms is generally caused by several things including the presence of disruptive compounds on the cell walls, causing increased cell membrane permeability resulting in loss of cell components, inactivity of enzymes in cells, and the process of destruction or damage to genetic material (Kirani Paramita et al., 2014). 
Table 2. The inhibition zone test against Escherichia coli

\begin{tabular}{cc}
\hline Biocomposite & $\begin{array}{c}\text { The area of } \\
\text { inhibition }\left(\mathbf{m m}^{\mathbf{2}}\right)\end{array}$ \\
\hline $\mathbf{0}$ & $7.00 \pm 0.05$ \\
$\mathbf{1}$ & $7.20 \pm 0.05$ \\
$\mathbf{2}$ & $8.50 \pm 0.05$ \\
$\mathbf{3}$ & $7.00 \pm 0.05$ \\
$\mathbf{4}$ & $7.00 \pm 0.05$ \\
$\mathbf{5}$ & $7.00 \pm 0.05$ \\
-(DMSO) & $0.00 \pm 0.05$ \\
+ (Chloramphenicol) & $78.5 \pm 0.05$ \\
\hline
\end{tabular}

On the other hand, the addition of chitosan concentration did not show an increment in the area of inhibition. This could be due to the limited ability of chitosan to bind nanocellulose. Based on the chemical structure of nanocellulose and chitosan, the bonds that occured in biocomposite is strong hydrogen bonds and between ammonium and hydroxyl group of chitosan and hydroxyl group of nanocellulose. Not all nanocellulose can be bound by chitosan because of the dissolution difficulty of nanocellulose and chitosan (Abdul Khalil et al., 2016). The biocomposite 2 with mass ratio 10:2 was chosen to be the most optimum composition and then the mechanical and morphological properties were tested.

\section{Biocomposite Membrane Thickness}

The biocomposite membrane thickness test was measured using a micrometer with a minimum scale of $0.01 \mathrm{~mm}$. Due to the very small thickness of the membrane, to facilitate the measurement, eight membranes were stacked and measurements were made at five different points. The thickness measurement results are then divided by eight and averaged. Based on the measurement results, it was known that the membrane thickness with the ratio NC-SB/CHIT (10: 2) was $0.0355 \mathrm{~mm} \pm$ $0.005 \mathrm{~mm}$, while the membrane thickness with the ratio NC-SB/CHIT (10: 3) was 0.0386 $\mathrm{mm} \pm 0.005 \mathrm{~mm}$. It was shown that the higher the chitosan concentration in the bicomposite, the thicker the membrane formed. This was influenced by the presence of biocomposite aggregation factors during the membrane printing process. In addition, this increase in thickness was due to the addition of mass of chitosan biopolymer which binds to nanocellulose which caused the thickness of the plastic to increase (Table 3).

Table 3. The biocomposite membrane thickness

\begin{tabular}{cc}
\hline Biocomposite & Thickness $(\mathbf{m m})$ \\
\hline $\mathbf{0}$ & $0.0135 \pm 0.005$ \\
$\mathbf{1}$ & $0.0235 \pm 0.005$ \\
$\mathbf{2}$ & $0.0255 \pm 0.005$ \\
$\mathbf{3}$ & $0.0287 \pm 0.005$ \\
$\mathbf{4}$ & $0.0302 \pm 0.005$ \\
$\mathbf{5}$ & $0.0312 \pm 0.005$ \\
\hline
\end{tabular}

\section{Morphology of Biocomposite}

Figure 3A shows the morphology of bagasse at 2,000x magnification, Figure 3B shows the morphology of nanocellulose at 10,000x magnification, Figure 3C shows the morphology of chitosan film and Figure 3D shows the surface morphology of the biocomposite nanocellulose-chitosan membrane at $10,000 \mathrm{x}$ magnification, respectively. From Figure 3A to Figure 3B, It shows the surface of sugarcane bagasse was smoother than nanocellulose because the outer layer of sugarcane bagasse have noncellulosic layer, shuch us pectin, lignin, wax, and hemicellulose that acted as cementing materials to hold the cellulose fibers in bundles (Chowdhury \& Hamid, 2016). The dimension of fiber was decrease because of the amorphous region removal in cellulose. Ultrasonication in the presence of sulfuric acid can hydrolyzed the nanocellulose amorphous region.

Morphological differences of chitosan and chitosan-nanocellulose biocomposite film can be observed through Figure 3C and 3D at $25,000 \mathrm{x}$ magnification. In the chitosan layer, separate granules are visible, while in the chitosan-nanocellulose biocomposite, there are no granules. This shows that the addition of nanocellulose to the chitosan layer can affect the stability of the layer structure so that it can affect the mechanical properties of the layer. Therefore, the increase in antibacterial activity in these biocomposites can be caused by the structural stability of the film layer.

\section{FT-IR Analysis}

FT-IR analyisis was used to characterize the effect of nanocellulose addition on chitosan films. The shifts of FT-IR bands are usually related to interaction between molecules. The spectra of pure 
nanocellulose and chitosan were used as references. The spectra of chitosannanocellulose blend and nanocellulose were shown to highlight differences among the sample structures (Figure 4).
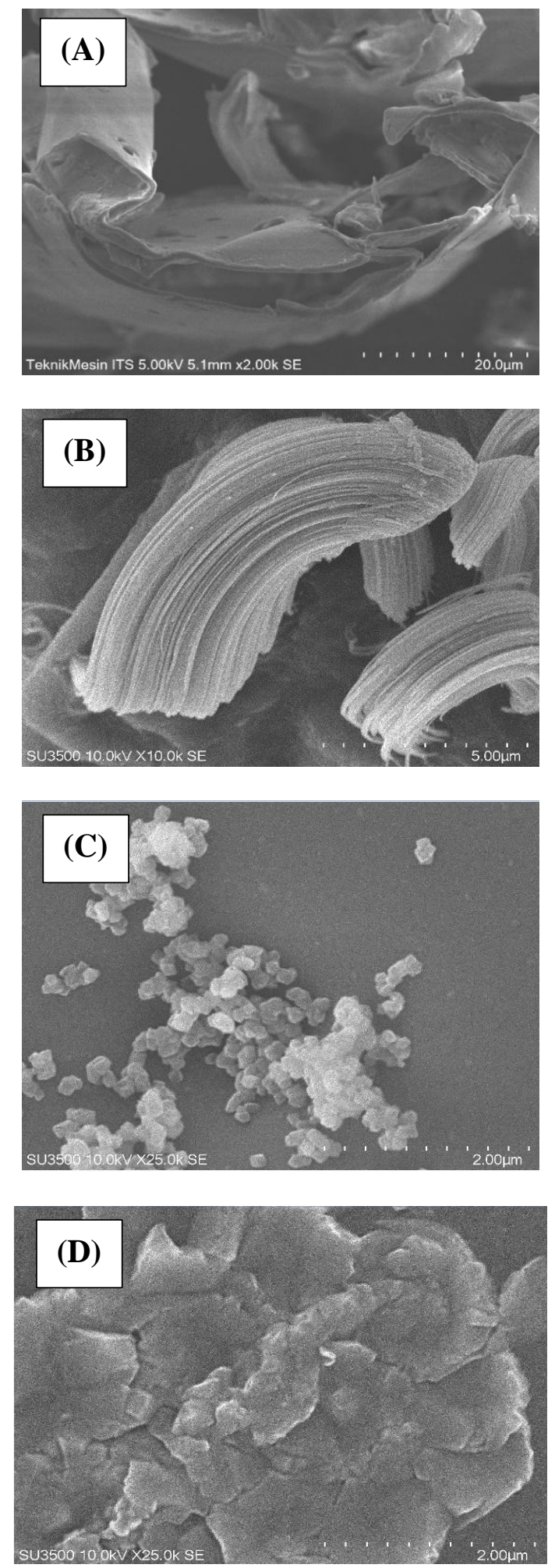

Figure 3. Micrograph of (A) sugarcane bagasse; (B) nanocellulose; (C) chitosan film (D) nanocellulose-chitosan biocomposite (10:2)

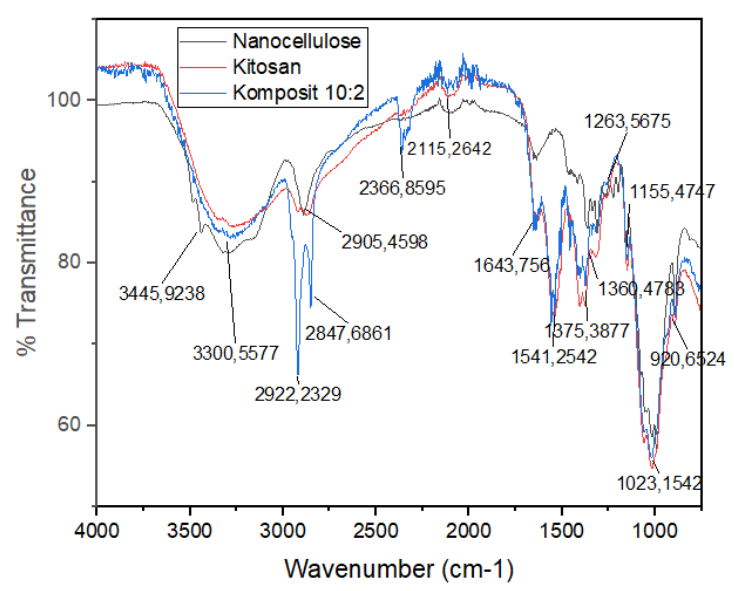

Figure 4. FT-IR spectra of chitosan, nanocellulose, and biocomposite of chitosan/nanocellulose

The nanocellulose spectra contain typical bands for cellulose. The region between 3,600 and $3200 \mathrm{~cm}^{-1}$ is assigned to O$\mathrm{H}$ stretching vibration with the maximum $\% \mathrm{~T}$ at $3300 \mathrm{~cm}^{-1}$ related to $\mathrm{O}-\mathrm{H}$ vibration due to hydrogen intramolecular bonding (Szymańska-Chargot et al., 2019). The region between $3000-2800 \mathrm{~cm}^{-1}$ is related to $-\mathrm{CH}$ and $-\mathrm{CH}_{2}$ stretching vibration. The region between $1,500-1250 \mathrm{~cm}^{-1}$ is related to - $\mathrm{CH}$ deformation and -OH out-of-plane bending vibration ( $\mathrm{Li}$ and Renneckar, 2011; Zhbankov et al., 2002). The region between 1,180 and $800 \mathrm{~cm}^{-1}$ has the same pattern for nanocellulose and chitosan film due to their similarity of molecular structure. This region is also sensitive for the $\mathrm{C}-\mathrm{O}$ and $\mathrm{C}-\mathrm{C}$ stretching vibration (Szymańska-Chargot et al., 2019). The main characteristic is the presence of bands at $1610 \mathrm{~cm}^{-1}$ (overlapped by water band at $1640 \mathrm{~cm}^{-1}$ ) related to $\mathrm{C}=\mathrm{O}$ stretching vibration, while bands at $1740 \mathrm{~cm}^{-1}$ are related to ester stretching vibration. This results in cellulose oxidation as an outcome of bleaching process with $\mathrm{NaOCl}$ ( $\mathrm{Li}$ and Renneckar 2011; Szyman'ska-Chargot et al., 2019).

There are some differences on FT-IR spectrum of biocomposite and chitosan. There was an increase in\% $\mathrm{T}$ in the area between 2900-2800 $\mathrm{cm}^{-1}$ at biocomposite spectrum. This indicates that there is an increase in the number of $-\mathrm{CH}$ and $-\mathrm{CH}_{2}$ vibrations originating from $-\mathrm{CH}$ and $-\mathrm{CH}_{2}$ nanocelluloses. In addition, the biocomposite spectrum has a band in the 2366 region which indicates a conjugated $\mathrm{C}=\mathrm{C}$ bond, while the other two spectra have no band in that region. 
A compound with the conjugated $\mathrm{C}=\mathrm{C}$ double bond has high reactivity with a stable structure. These properties are due to the fact that the electrons in the phi bond can resonate with the conjugation of the double bond at $\mathrm{C}=$ C (Warren, 2008). Therefore, the presence of this conjugated $\mathrm{C}=\mathrm{C}$ double bond can increase the antibacterial activity of a material.

\section{XRD Analysis}

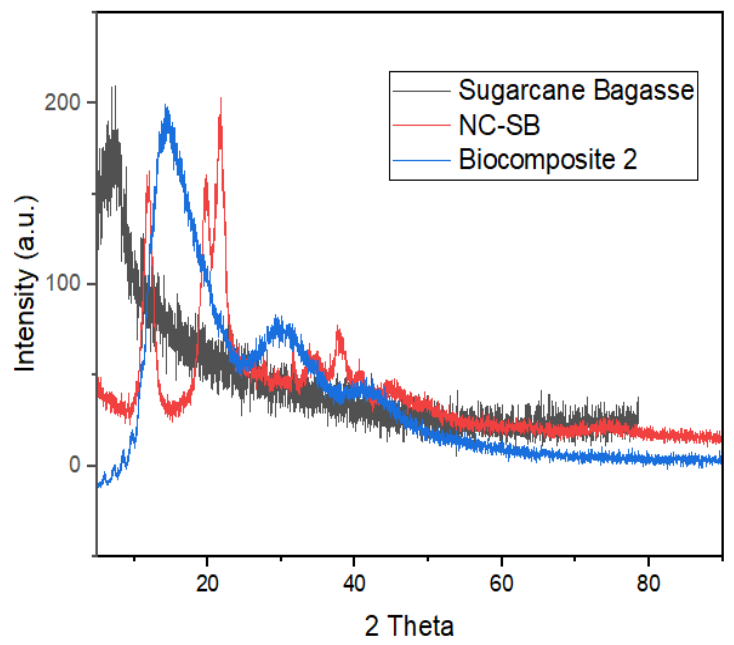

Figure 5. Diffractogram of NC-SB and biocomposite 2

Figure 5 shows the XRD patterns for sugarcane bagasse and nanocellulose (NCSB). All of XRD patterns showed peaks around $2 \theta$ of $5-22^{\circ}$ indicating the typical cellulose I structure. The only difference was slight intensity change in the peaks that indicating some change in the crystallinity index of samples (Subramanian et al., 2005). The NC-SB peak at $5-25^{\circ}$ more defined than Sugarcane Bagasse peak. This was indicated that acid hydrolysis and ultrasonic wave can increase the crystallinity index of cellulose. During the acid hydrolysis process, hemicellulose and lignin were dissolved and the remaining pure of cellulose were isolated. The particle can increases peak intensity and give narrower crystalline peaks (Rosli et al., 2013). Biocomposite 2 (CHIT/NC-SB) showed different XRD pattern at $2 \theta$ range from $5^{\circ}$ to $40^{\circ}$ that indicated the presence of chitosan in composite. The presence of chitosan showed that the nanocellulosechitosan biocomposite had formed successfully.

\section{\% Moisture content analysis}

Moisture analysis aims to see the effect of nanocellulose addition on the physical properties of chitosan film (Table 4). Based on the data in table 4, chitosan has the highest $\%$ moisture than other materials at $7.75 \%$. With the addition of nanocellulose in the chitosan film, the chitosan moisture decreased to $5.24 \%$ (Biocomposite 2). This decrease in\% moisture content affects the antibacterial activity of a substance. Bacteria easily grow in places with high humidity. Therefore, in this study the\% moisture of the material is thought to affect its antibacterial activity. It is evident that biocomposite 2 has a larger zone of inhibition against the growth of Escherichia coli than chitosan film (Table 2).

Table 4. Moisture content analysis

\begin{tabular}{lc}
\hline \multicolumn{1}{c}{ Sample } & \% Moisture Content \\
\hline Sugarcane bagasse & 1.47 \\
NC-SB & 3.85 \\
Chitosan & 7.75 \\
Biocomposite 2 & 5.24 \\
\hline
\end{tabular}

\section{CONCLUSION}

Based on the research results, the nanocellulose-chitosan biocomposite membrane was able to inhibit the growth of the Escherichia coli bacteria. In addition, the inhibition of the biocomposite membrane (10: 2) was better than the inhibition of chitosan against Escherichia coli. SEM characterization shows that the addition of nanocellulose can affect the stability of the layer structure, meanwhile FT-IR spectrum shows that biocomposite has conjugated double bond $\mathrm{C}=\mathrm{C}, \mathrm{A}$ compound with the conjugated $\mathrm{C}=\mathrm{C}$ double bond has high reactivity with a stable structure, XRD analysis indicating that there is a change in crystallinity index of nanocellulose and biocomposite. Based on the characterization results, it can be concluded that nanocellulose-chitosan biocompoite was successfully formed, and based on the antibacterial activity study, the addition of nanocellulose on chitosan film can increase their antibacterial activity against Escherichia coli.

\section{ACKNOWLEDGMENT}

The author would like to thank the Ministry of Research, Technology and Higher 
Education who has provided research grant 2020 through Beginner lecturer research schemes with contract number 083/SP2H/LT/DRPM/2020; 128/SP2H/LTMONO/LL7/2020; 004/STIKESRSAM/SPPenelitian/III/2020.

\section{REFERENCES}

Abdul Khalil HPS, Saurabh CK, Adnan AS, Nurul Fazita MR, Syakir MI, Davoudpour Y, Rafatullah M, Abdullah CK, Haafiz MKM, Dungani R. 2016. A review on chitosancellulose blends and nanocellulose reinforced chitosan biocomposites: Properties and their applications. Carbohydrate Polymers. 150: 216226.

https://doi.org/10.1016/j.carbpol.2016. 05.028

Amanda ER, Khoirun N, Yulianto AP. 2020. Pengembangan bioplastik antibakteri Morgonella morganii sebagai kemasan makanan. Jurnal Kimia Dan Kemasan. 42(1): 29-36.

Calcott PH. 1982. Cyclic AMP and cyclic GMP control of synthesis of constitutive enzymes in Escherichia coli. Journal of General Microbiology. 128(4): 705-712. https://doi.org/10.1099/00221287-1284-705

Cheung RCF, Ng TB, Wong JH, Chan WY. 2015. Chitosan: An update on potential biomedical and pharmaceutical applications. In Marine Drugs. 13(8): https://doi.org/10.3390/md13085156

Chowdhury ZZ, Hamid SBA. 2016. Preparation and characterization of nanocrystalline cellulose using ultrasonication combined with a. BioResources. 11(2): 3397-3415.

Effendi DB, Rosyid NHR, Nandiyanto ABD, Mudzakir A. 2015. Review: sintesis nanoselulosa. Jurnal Integrasi Proses. 5(2): 61-74. https://doi.org/10.1371/journal.pone.0 057607
George J, Sabapathi SN. 2015. Cellulose nanocrystals: Synthesis, functional properties, and applications. Nanotechnology, Science and Applications. $\quad 8:$ 45-54. https://doi.org/10.2147/NSA.S64386

Gunathilake TMSU, Ching YC, Chuah $\mathrm{CH}$. 2017. Enhancement of curcumin bioavailability using nanocellulose reinforced chitosan hydrogel. Polymers. $\quad 9(2)$ : 64. https://doi.org/10.3390/polym9020064

Hadi U, Kuntaman K, Qiptiyah M, Paraton H. 2013. Problem of antibiotic use and antimicrobial resistance in Indonesia: are we really making progress. Indonesian Journal of Tropical and Infectious Disease. 4(4): 5. https://doi.org/10.20473/ijtid.v4i4.222

Hänninen A, Sarlin E, Lyyra I, Salpavaara T, Kellomäki M, Tuukkanen S. 2018. Nanocellulose and chitosan based films as low cost, green piezoelectric materials. Carbohydrate Polymers. 202(September): $\quad 418-424$. https://doi.org/10.1016/j.carbpol.2018. 09.001

Kim SH, Schneider BL, Reitzer L. 2010. Genetics and regulation of the major enzymes of alanine synthesis in Escherichia coli. Journal of Bacteriology. 192(20): 5304-5311. https://doi.org/10.1128/JB.00738-10

Kirani PD, Semadi AN, Wayan GI. 2014. Inhibition activity of essential oil of lemongrass leaves (Cymbopogon citratus) on the growth of Escherichia coli, Staphylococcus aureus, and Vibrio cholerae. Jurnal Rekayasa Dan Manajemen Agroindustri. 2(1): 29-38.

Li J, Wei X, Wang Q, Chen J, Chang G, Kong L, Su J. 2012. Homogeneous isolation of nanocellulose from sugarcane bagasse by high pressure homogenization. Carbohydrate Polymers. $\quad 90(4)$ : 1609-1613. https://doi.org/10.1016/j.carbpol.2012. 07.038 
Li, Juanjuan, Cha, R., Mou, K., Zhao, X., Long, K., Luo, H., Zhou, F., \& Jiang, X. (2018). Nanocellulose-Based Antibacterial Materials. Advanced Healthcare Materials, 7(20), 1-16. https://doi.org/10.1002/adhm.2018003 34

Mandal A, Chakrabarty D. 2011. Isolation of nanocellulose from waste sugarcane bagasse (SCB ) and its characterization. Carbohydrate Polymers. $\quad 86(3)$ : 1291-1299. https://doi.org/10.1016/j.carbpol.2011. 06.030

Nieß A, Siemann-Herzberg M, Takors R. 2019. Protein production in Escherichia coli is guided by the trade-off between intracellular substrate availability and energy cost 06 biological sciences 0601 biochemistry and cell biology. Microbial Cell Factories. 18(1): 1-10. https://doi.org/10.1186/s12934-0191057-5

Oksman K, Aitomäki Y, Mathew AP, Siqueira G, Zhou Q, Butylina S, Tanpichai S, Zhou X, Hooshmand S. 2016. Review of the recent developments in cellulose nanocomposite processing. Composites Part A: Applied Science and Manufacturing. 83: 2-18. https://doi.org/10.1016/j.compositesa.2 015.10 .041

Phanthong P, Reubroycharoen P, Hao X, Xu G, Abudula A, Guan G. 2018. Nanocellulose: extraction and application. Carbon Resources Conversion. 1(1): 32-43. https://doi.org/10.1016/j.crcon.2018.05 .004

Rahmi AYUF. 2017. Adsorpsi protein oleh nanoselulosa berbasis ampas tebu ( bagasse) dengan metode hidrolisis asam. Jember(ID): Jursan Kimia Fakultas Matematika dan Ilmu pengetahuan Alam Universitas Jember.

Ribeiro RSA, Pohlmann BC, Calado V, Bojorge N, Pereira N. 2019.
Production of nanocellulose by enzymatic hydrolysis: Trends and challenges. Engineering in Life Sciences. 19(4): 279-291. https://doi.org/10.1002/elsc.20180015 8

Rosli NA, Ahmad I, Abdullah I. 2013. Isolation and characterization of cellulose nanocrystals from agave angustifolia fibre. BioResources. 8(2): 1893-1908.

https://doi.org/10.15376/biores.8.2.189 3-1908

Saputri LH, Sukmawan R, Santoso H, Rochardjo B. 2018. Isolasi Nano Selulosa dari Ampas Tebu dengan Proses Blending pada Berbagai Variasi Konsentrasi. April, 1-6.

Shahi N, Min B, Sapkota B, Rangari VK. 2020. Eco-friendly cellulose nanofiber extraction from sugarcane bagasse and film fabrication. Sustainability (Switzerland). 12(15): 1-15. https://doi.org/10.3390/su12156015

Sheltami RM, Abdullah I, Ahmad I, Dufresne A, Kargarzadeh H. 2012. Extraction of cellulose nanocrystals from mengkuang leaves (Pandanus tectorius). Carbohydrate Polymers. 88(2): 772-779. https://doi.org/10.1016/j.carbpol.2012. 01.062

Subramanian K, Senthil KP, Jeyapal P, Venkatesh N. 2005. Characterization of ligno-cellulosic seed fibre from Wrightia Tinctoria plant for textile applications-an exploratory investigation. European Polymer Journal. 41(4): 853-861. https://doi.org/10.1016/j.eurpolymj.20 04.10 .037

Szymańska-Chargot M, Chylińska M, Pertile G, Pieczywek PM, Cieślak KJ, Zdunek A, Frąc M. 2019. Influence of chitosan addition on the mechanical and antibacterial properties of carrot cellulose nanofibre film. Cellulose. 26(18): 9613-9629. https://doi.org/10.1007/s10570-019- 
02755-9

Wulandari WT, Rochliadi A, Arcana IM. 2016. Nanocellulose prepared by acid hydrolysis of isolated cellulose from sugarcane bagasse. IOP Conference Series: Materials Science and Engineering. 107(1). https://doi.org/10.1088/1757-
899X/107/1/012045

Xu Q, Ji Y, Sun Q, Fu Y, Xu Y, Jin L. 2019. Fabrication of cellulose nanocrystal/chitosan hydrogel for controlled drug release. Nanomaterials.

9(2).https://doi.org/10.3390/nano9020 253 